\title{
Cerebellar Disorganization Characteristic of Reeler in Scrambler Mutant Mice Despite Presence of Reelin
}

\author{
Dan Goldowitz, ${ }^{1}$ Richard C. Cushing, ${ }^{1}$ Eric Laywell,, Gabriella D'Arcangelo, ${ }^{2}$ Michael Sheldon, ${ }^{2}$ \\ Hope O. Sweet, ${ }^{3}$ Muriel Davisson, ${ }^{3}$ Dennis Steindler, ${ }^{1}$ and Tom Curran ${ }^{2}$ \\ ${ }^{1}$ Department of Anatomy and Neurobiology, University of Tennessee College of Medicine, Memphis, Tennessee 38163, \\ 2Department of Developmental Neurobiology, St. Jude Children's Research Hospital, Memphis, Tennessee 38105, and \\ ${ }^{3}$ The Jackson Laboratory, Bar Harbor, Maine 04609
}

\begin{abstract}
Analysis of the molecular basis of neuronal migration in the mammalian CNS relies critically on the discovery and identification of genetic mutations that affect this process. Here, we report the detailed cerebellar phenotype caused by a new autosomal recessive neurological mouse mutation, scrambler (gene symbol scm). The scrambler mutation results in ataxic mice that exhibit several neuroanatomic defects reminiscent of reeler. The most obvious of these lies in the cerebellum, which is small and lacks foliation. Granule cells, although normally placed in an internal granule cell layer, are greatly reduced in number ( $20 \%$ of normal). Purkinje cells are also reduced in number, and the majority are located ectopically in deep cerebellar masses. There is a small population of Purkinje cells ( $\sim 5 \%$ of the total) that occupy a Purkinje cell layer between the molecular and granule cell layers. Despite this apparent disorganization of Purkinje cells, zebrin-positive and zebrin-negative parasagittal zones can be delineated. The ectopic masses of
\end{abstract}

Purkinje cells are bordered by the extracellular matrix protein tenascin and by processes containing glial fibrillary acidic protein. Antibodies specific for these proteins also identify a novel midline raphe structure in both scrambler and reeler cerebellum that is not present in wild-type mice. Thus, in many respects, the scrambler cerebellum is identical to that of reeler. However, the scrambler locus has been mapped to a site distinct from that of reelin $(R e / n)$, the gene responsible for the reeler defect. Here we find that there are normal levels of Reln mRNA in scrambler brain and that reelin protein is secreted normally by scrambler cerebellar cells. These findings imply that the scrambler gene product may function in a molecular pathway critical for neuronal migration that is tightly linked to, but downstream of, reelin.

Key words: scrambler; reeler; Purkinje cell; cerebellar granule cell; neuronal ectopia; neuronal migration; cerebellar mutants; reelin; disabled
During development, the nervous system is assembled by an orchestrated series of cell migrations. The isolation and characterization of neurodevelopmental mutations in the mouse have provided keys to understanding the complex molecular events involved in establishing brain structure and function. Several specific gene mutations have been identified that perturb neuronal migration in mice and humans (Franco et al., 1991; Legouis et al., 1991; Hattori et al., 1994; D’Arcangelo et al., 1995; Reiner et al., 1995). Among these, reeler stands apart as an archetypal mutation associated with profound disturbances of laminar structures throughout the brain (Caviness, 1977; Goffinet, 1984). In the cerebral cortex, the so-called inside-out migratory pattern appears to be inverted (Caviness et al., 1981; Caviness, 1982; Hoffarth et al., 1995). The most dramatic effects of the reeler mutation are seen in the cerebellum, which is severely reduced in size and lacks obvious foliation (Mariani et al., 1977; Goffinet, 1983, 1984). Purkinje cells remain in ectopic masses deep to the

Received Aug. 4, 1997; accepted Aug. 7, 1997.

This research was supported by National Institutes of Health Grant NS23475 and aid from the University of Tennessee College of Medicine Bridge Fund and the Department of Anatomy and Neurobiology (D.G.), National Institutes of Health Grants NS29225 (D.S.), P40 RR01183 and NSF DBI 9502221 (M.D.), and P30 CA21765 (T.C.), the American Lebanese Syrian Associated Charities (T.C.), and National Research Service Awards NS09698 (G.D.) and CA62590 (M.S.). We thank Dr. Richard Smeyne for help in image processing.

Correspondence should be addressed to Dr. Dan Goldowitz, Department of Anatomy and Neurobiology, University of Tennessee College of Medicine, 855 Monroe Avenue, Memphis, TN 38163.

Copyright (C) 1997 Society for Neuroscience $0270-6474 / 97 / 178767-11 \$ 05.00 / 0$ granule cell layer, and although granule cells are positioned normally, they are markedly reduced in number.

The reeler gene (Reln) and its product (reelin) have been identified recently (D'Arcangelo et al. 1995). Reelin is a large secreted protein made by the first born neurons in neocortex (the Cajal-Retzius cells; D'Arcangelo et al. 1995; Hirotsune et al., 1995; Ogawa et al., 1995) and cerebellum (deep nuclear neurons; Miyata et al., 1996). The identification of Reln offers the exciting possibility of understanding the molecular underpinnings of neuronal migration in widespread regions of the brain.

Here we present an analysis of a new autosomal recessive mutation in the mouse, scrambler (gene symbol scm) (Sweet et al., 1996) that has defects in neuronal positioning similar to those described in reeler. Neuroanatomic analyses coupled with immunocytochemical studies indicate that the scrambler cerebellum is remarkably similar to that of reeler. However, Reln mRNA is present at normal levels in scrambler brain, and reelin is secreted normally from scrambler cerebellar cells. Thus, because reelin appears to be normal in scrambler mice, the close parallels in the phenotypes suggest that $\mathrm{scm}$ may represent a component of a signal transduction pathway that lies downstream of reelin in the control of neuronal migration.

\section{MATERIALS AND METHODS}

Mice. The scrambler mutation arose on the dancer (DC/Le) strain of mice, and mutants were outcrossed once to the $\mathrm{C} 3 \mathrm{HeB} / \mathrm{FeJLe}$ strain. The stock is maintained by sibling matings (Sweet et al., 1996). Our colony at the University of Tennessee was obtained from the Jackson 
Laboratory. Homozygous mutants are ataxic; their walk is straight but it is marked by a front-to-back jerkiness that is often interrupted by rearing onto their hindquarters. Homozygous females are fertile, but they must be held with their parents past the normal weaning age of 3 weeks to survive to breed. Homozygous males have not been reproductively successful and appear infertile. The colony is maintained by mating heterozygous males to either homozygous or heterozygous female mutants Mice are kept on a 14/10 hr day/night cycle with food and water ad libitum. For comparative analysis, reeler mice (the Edinburgh mutation maintained at The Jackson Laboratory on the C57BL/6J $\times \mathrm{C} 3 \mathrm{HeB} /$ FeJLe-a/a strain background) and littermate controls were used. These animals were purchased from The Jackson Laboratory and maintained in our facility as a breeding colony. All mice were treated in accordance with Society for Neuroscience policy on the use of animals in research.

Tissue preparation. Mature (age 30-180 d) or young mice (postnatal age 5-7 d) were deeply anesthetized with Avertin before transcardial perfusion with fixative. Adult mutant and control mice were perfused first with a $0.1 \mathrm{M}$ PBS solution, $\mathrm{pH} 7.2$, followed by a $3: 195 \%$ ethanol/ acetic acid solution. Whole heads were post-fixed in the $95 \%$ ethanol/ acetic acid solution overnight. Brains were removed, rinsed, and stored in $70 \%$ ethanol and processed for paraffin embedding.

Postnatal day 5-7 (P5-P7) scrambler mutants and normal littermates were deeply anesthetized and transcardially perfused with a $4 \%$ paraformaldehyde fix (in $0.1 \mathrm{M}$ PBS). Cerebella were removed and cut with a vibratome into $40 \mu \mathrm{m}$ sections through the coronal plane. Some cerebella were flattened tangentially overnight between glass coverslips before sectioning in the parasagittal plane.

Birth-dating analysis. Young pups and timed-pregnant females received one injection of bromodeoxyuridine (BrdU; $50 \mu \mathrm{g} / \mathrm{gm}$; Sigma, St. Louis, MO) at either postnatal day $0,5,11,15$, or 21 or embryonic day $10.5,11.5,12.5,13.5$, or 16.5 [with midnight of vaginal plug considered embryonic day $0(\mathrm{E} 0)$ ]. Mice received intraperitoneal injections of mitotic label and were killed when at least $30 \mathrm{~d}$ of age. The BrdU-labeling method has been described previously (Hamre and Goldowitz, 1996). Tissue for BrdU was paraffin-sectioned and processed for immunocytochemistry using the mouse monoclonal antibody to the BrdU (Becton Dickinson, San Jose, CA), followed by detection with anti-mouse secondary antibody and diaminobenzidine detection. Cells that incorporated BrdU exhibited a dense brown reaction product in the nucleus.

Immunocytochemistry. Antibodies to the following antigens were used to assess phenotypic characteristics of the scrambler cerebellum. Anticalbindin D-28K (a gift from M. Celio, University of Fribourg, Fribourg, Germany; used at a dilution of $1: 1,000$ ) was used to stain Purkinje cells; anti-zebrin II antibody (a gift from Richard Hawkes, University of Calgary, Calgary, Alberta, Canada; used at a dilution of 1:50) was used for staining Purkinje cells in parasagittal bands; anti-glial fibrillary acidic protein (GFAP) staining was used to mark glia (used at a dilution of 1:25; Immunon, Pittsburgh, PA); and anti-tenascin staining was used to highlight the extracellular matrix (a polyclonal antibody raised against the tenascin fusion protein; a gift from M. Schachner, ETH, Zurich, Switzerland; used at a dilution of 1:500).

Sections of adult brain were stained at room temperature overnight with antibodies to calbindin and zebrin and then rinsed the following day before application of secondary biotinylated antibody. Immunopositive cells were detected with diaminobenzidine as the chromogen (ABC Elite kit; Vector Laboratories, Burlingame, CA) or via a fluoresceinated secondary antibody. Flattened tangential sections were processed for immunocytochemistry with anti-GFAP, anti-tenascin, and anti-calbindin (1:1,000, Sigma) antibodies.

Morphological analyses. The cerebella from adult scrambler $(\mathrm{scm} / \mathrm{scm})$, reeler $\left(\operatorname{Reln}^{r l} / \operatorname{Reln}^{r l}\right)$, and phenotypically normal cerebella $(+/+$ or $+/ \mathrm{scm}$ derived from homozygous scrambler females) were reconstructed in the sagittal and coronal planes from every 20th or 40th $6 \mu \mathrm{m}$ section through the cerebellum with the aid of the three-dimensional reconstruction program of the Neurolucida imaging system. The total volume as well as rostral-caudal and dorsal-ventral extents of the cerebellum were ascertained. Zebrin-positive and zebrin-negative bands of Purkinje cells were also reconstructed from every 40th section using this software.

Purkinje cells were counted in anti-calbindin-stained material from scrambler, reeler, and control brains. All calbindin-positive cells with a distinct, unstained nucleus were counted in every 20 th or 40 th $6 \mu \mathrm{m}$ section throughout one-half of the cerebellum. In mutant brains the number of normally positioned Purkinje cells, relative to the total number of ectopically placed Purkinje cells, was determined. Total numbers of Purkinje cells were determined using the method of Abercrombie
(1946), correcting for split nuclei. The Purkinje cell nucleus in a random sample of 20-50 cells averaged $8.5 \mu \mathrm{m}$ in scrambler, reeler, and control brains. Granule cells were counted in single midline sections. The average density of granule cells was estimated from sampling six random $10,000 \mu \mathrm{m}^{2}$ regions in the granule cell layer. The average density was multiplied by the total granule cell area to arrive at an estimate of total granule cells per cerebellar section.

Northern analysis. Whole brains were dissected from postnatal day 12-14 mice homozygous for the scrambler and reeler mutations as well as from normal littermates. Total RNA was isolated using the rapid RNA isolation kit (5 Prime $\rightarrow 3$ Prime, Inc., Boulder, CO). Samples (10 $\mu \mathrm{g} /$ lane) were electrophoresed through a $1 \%$ formaldehyde-agarose gel and transferred onto a nylon membrane (Hybond; Amersham, Arlington Heights, IL). The reelin RNA was detected using a $\left[{ }^{32} \mathrm{P}\right]$ uridine triphosphate-labeled riboprobe corresponding to nucleotides 2425-3348 of the cDNA sequence deposited in GenBank (accession number U24703). The riboprobe was synthesized using a commercial kit (Promega, Madison, WI). Hybridization was performed at $68^{\circ} \mathrm{C}$ in standard hybridization buffer containing $50 \%$ formamide. Signal was visualized by exposing the gel to Kodak (Rochester, NY) MS x-ray film. Ethidium bromide staining was used to confirm that similar amounts of RNA were loaded in each lane.

Immunoprecipitation. The cerebellum was removed by dissection from postnatal day 6 homozygous scrambler and normal littermate mice, chopped finely with a razor blade, and triturated with a pipette. Cells were resuspended in basal Eagle's medium supplemented as described previously (Fischer, 1982) with 5\% horse serum (HyClone, Logan, UT) and plated in tissue culture dishes that had been precoated with $20 \mu \mathrm{g} / \mathrm{ml}$ poly-L-lysine. Cultures were switched to serum-free medium $1 \mathrm{~d}$ after plating, and incubation was continued for an additional day. Neurite outgrowth during this period was indicative of healthy cultures.

Proteins expressed by cerebellar cells in culture were labeled overnight with a $300 \mu \mathrm{Ci} / \mathrm{ml}$ mixture containing $\left[{ }^{35} \mathrm{~S}\right]$ methionine and $\left[{ }^{35} \mathrm{~S}\right]$ cysteine (New England Nuclear, Boston, MA) in basal Eagle's media depleted of methionine (Cellgro) and supplemented as described previously (Fischer, 1982). For immunoprecipitation analysis, the culture medium was precleared by centrifugation at $1500 \mathrm{rpm}$ in a refrigerated Eppendorf microfuge for $10 \mathrm{~min}$. The supernatant was then collected and diluted 1:1 with $2 \times$ radioimmunoprecipitation assay (RIPA) buffer (50 mM Tris, $\mathrm{pH} 8,150$ $\mathrm{mm} \mathrm{NaCl}, 1 \%$ Nonidet P-40, $0.5 \%$ sodium deoxycholate, and $0.1 \%$ SDS). The anti-reelin monoclonal antibody CR-50 (Ogawa et al., 1995; D'Arcangelo et al., 1997) was added (2 $\mu$ l of ascites fluid in $300 \mu \mathrm{l}$ samples) and incubated at $4^{\circ} \mathrm{C}$ for $3 \mathrm{hr}$. Immobilized protein $\mathrm{G}$-agarose beads (Immunopure plus; Pierce, Rockford, IL) were added to precipitate the antibodies, and the samples were incubated for an additional 30 min. Immunoprecipitates were collected by centrifugation and washed three times with RIPA buffer. Samples were resuspended in $20 \mu$ l of SDS sample buffer, boiled, and loaded onto SDS-polyacrylamide gels (4-12\% gradient gels; Novex, San Diego, CA). Signal was visualized by exposing the gel to Kodak MS x-ray film.

\section{RESULTS}

\section{General appearance of scrambler}

The $\mathrm{scm} / \mathrm{scm}$ mouse has a relatively mild ataxia under normal home cage conditions, and it exhibits truncal swaying with a slightly jerky forward movement during locomotion. Mutant mice commonly interrupt forward progression and pause with weight on their hindquarters. Heterozygous mice appear completely normal.

The $\mathrm{scm} / \mathrm{scm}$ brain is smaller than that of normal mice primarily as a consequence of a smaller cerebral cortex and a much reduced cerebellum. The most prominent cytoarchitectonic abnormalities in the scrambler brain are the delaminated hippocampal formation and the reduced numbers and ectopia of granule cells and Purkinje cells in the cerebellum (Fig. 1B,D). These defects are similar to those seen in the brain of reeler mice (Fig. $1 C, E)$ and are not seen in the brain of heterozygous scrambler mice (Fig. 1A). The alterations in the scrambler cerebral cortex will be discussed in a subsequent manuscript (González et al., 1997). To a first approximation, in all of the above respects, the 


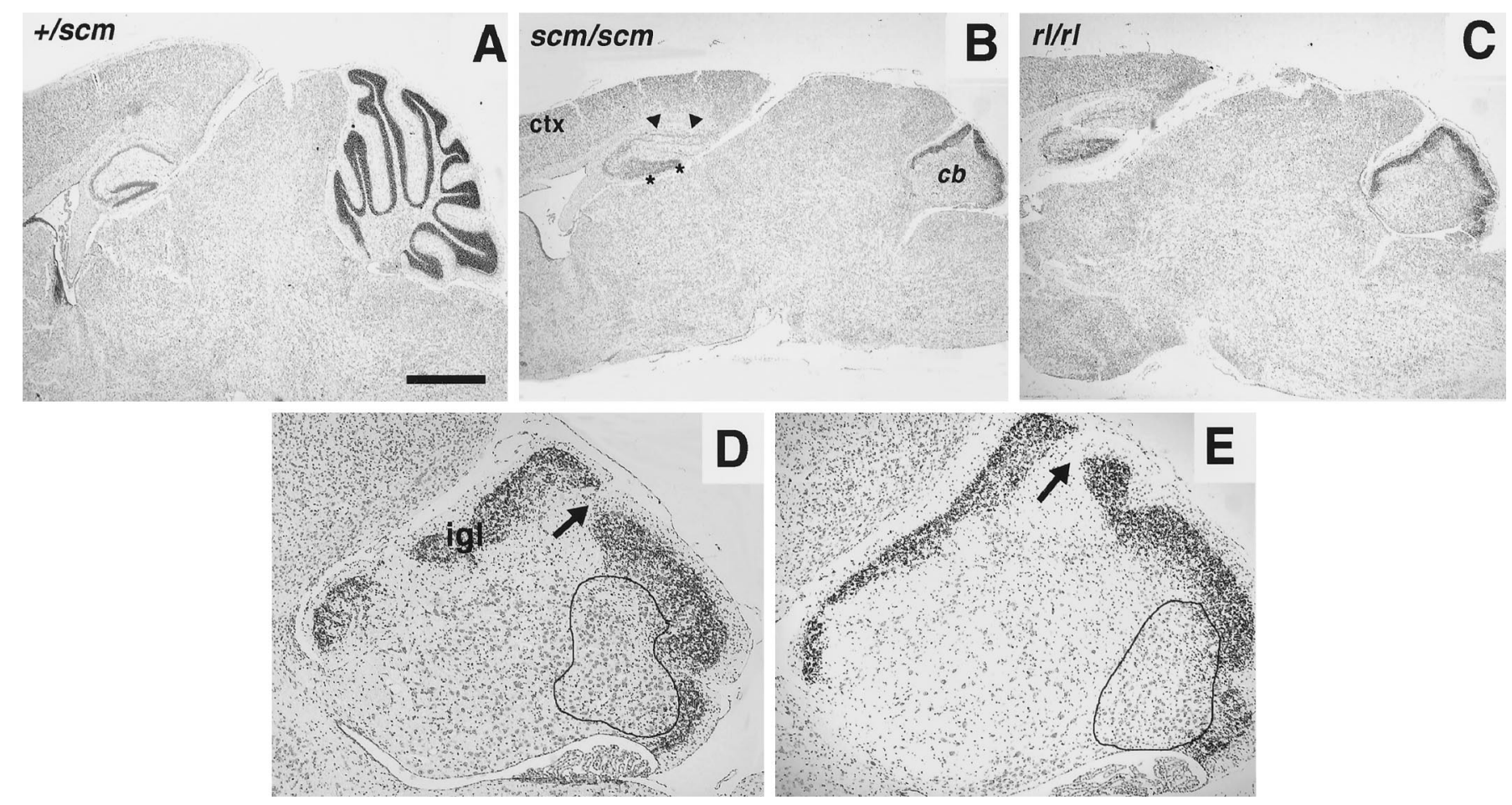

Figure 1. The scrambler mouse. A, A sagittal section of brain from a heterozygous scrambler littermate stained with cresyl violet shows the normal layering of cortex, hippocampus and dentate gyrus, and cerebellum. $B$, Sagittal view of a scrambler brain stained with cresyl violet. The cortex (ctx) is reduced in size and is void of a molecular layer; the pyramidal cells of hippocampus regio superior are scattered in several layers (double arrowheads); the granule cells of the dentate gyrus are irregularly clustered (asterisks); and the cerebellum $(\mathrm{cb})$ is unfoliated and markedly reduced in size. $C$, The reeler brain and cerebellum bear a striking resemblance to the scrambler brain and cerebellum in many details. $D$, A higher magnification view of the scrambler cerebellum shows the granule cells of the internal granule layer $(i g l)$ that are interrupted by a cell-free notch that is likely the vestigial primary fissure (arrow). Deep to the granule cell layer are clusters of numerous ectopic Purkinje cells. One large cluster is enclosed by a line. E, A higher magnification view of the reeler cerebellum demonstrates the unfoliated cerebellum, ring of igl granule cells, cell-free notch (arrow), and ectopic Purkinje cells (a large cluster enclosed by a line). These are several of the phenotypes that reeler shares with the scrambler cerebellum. Rostral is to the left, and caudal is to the right. Scale bar: $A-C, 1 \mathrm{~mm} ; D, E, 250 \mu \mathrm{m}$.

scrambler brain appears to be phenotypically equivalent to reeler (Fig. 1D,E).

\section{Qualitative features of the scrambler cerebellum}

The characteristic foliation of the cerebellum is missing in scrambler, and the cerebellar structure is greatly reduced in size (Fig. $1 B, D)$. The scrambler cerebellum has a fissure in the posterior vermis as well as a notch in the granular layer that likely represents the "vestigial" primary fissure described in the reeler cerebellum (Mariani et al., 1977) (Fig. 1D,E). The granule cell population is positioned in an internal granule cell layer that lies below a thin, relatively cell-free, molecular layer and a poorly populated Purkinje cell layer. Scrambler granule cells are greatly reduced in number. Immunocytochemical analysis using antibodies specific for calbindin reveals that the vast majority of Purkinje cells are found in several distinct clusters deep to the granule cell layer (Fig. 2A,B; compare with the wild-type placement of Purkinje cells in Fig. 2E,F). In coronal sections of the anterior cerebellum, Purkinje cells are primarily detected in several deep clusters aligned in the mediolateral dimension. At midposterior levels of the cerebellum there is a large mass of Purkinje cells that straddles the midline as well as two to three clusters that are placed laterally (Fig. $2 B$ ). In the most caudal aspect of the cerebellum, Purkinje cell clusters are less pronounced, and the granule cell layer is more prominent (data not shown). Another cluster of Purkinje cells is located just below the granule cell layer about midway along the mediolateral dimension (Fig. 2A). Cer- ebellar nuclear cells are located ventral to and between the ectopic clusters of Purkinje cells in three distinct clusters that appear to be similar to the middle, interposed, and lateral nuclei in the normal cerebellum (Fig. 2B). These features of the scrambler cerebellum are very similar to those of reeler (Goffinet et al., 1984). The only substantive difference between the two mutants is the placement of Purkinje cells in the region of the floccular lobe. In scrambler mice, Purkinje cells are largely placed ectopically, whereas in reeler mice there are many normally placed Purkinje cells with appropriately oriented dendritic trees (Fig. 2C,D).

Despite the grossly abnormal disposition of Purkinje cells in the reeler cerebellum, Purkinje cells are distributed in zebrinpositive and zebrin-negative parasagittal aligned zones (Edwards et al., 1994). To explore the parasagittal organization of scrambler Purkinje cells, coronal sections of $\mathrm{scm} / \mathrm{scm}$ cerebella were stained with an anti-zebrin II antibody. Zones of zebrin-positive and zebrin-negative Purkinje cells extended as strips from the sparsely populated Purkinje cell layer down through the deep Purkinje cell masses (Fig. 3A). In scrambler, as reeler, the anterior cerebellum is partitioned into a number of zebrin-positive and zebrin-negative bands. As is the reeler cerebellum, the more posterior scrambler cerebellum is composed of broader bands that are mostly zebrin-positive (Fig. $3 B$ ). To compare the zebrin banding pattern in the scrambler cerebellum with that of reeler, a reconstruction of every 40th section from two $\mathrm{scm} / \mathrm{scm}$ and one $\operatorname{Reln}^{r l} / \operatorname{Reln}^{r l}$ cerebellum was prepared. The basic similarities of 

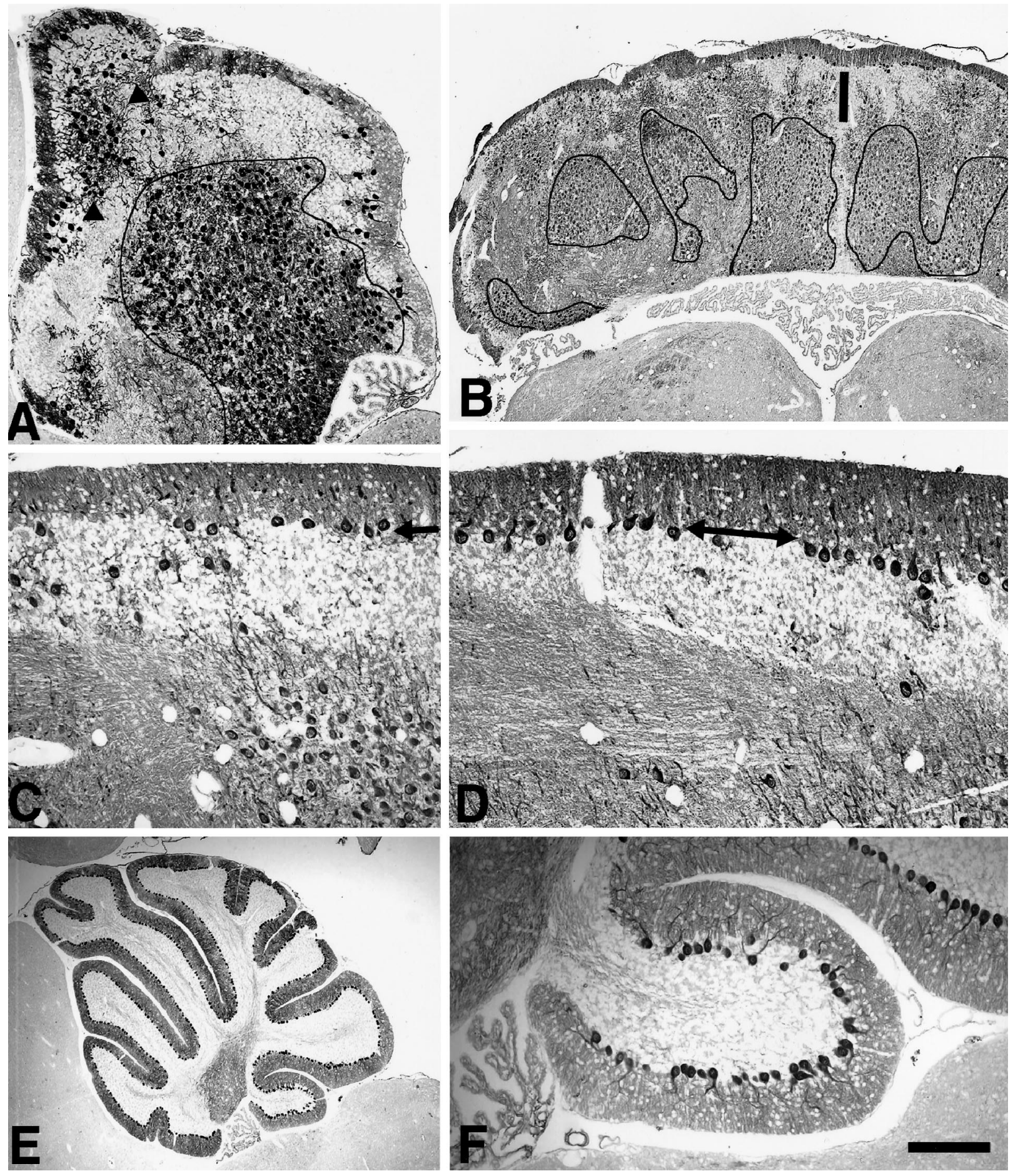

Figure 2. Purkinje cell placement in the scrambler cerebellum in anti-calbindin immunostained material. $A$, Sagittal section shows the large, ectopic cluster (region enclosed by line) as well as ectopically clustered Purkinje cells deep to the granule cell layer in the rostral cerebellum (arrowheads) and a scattering of normally positioned Purkinje cells. $B$, A lower magnification coronal view of the cerebellum shows the medial-lateral disposition of ectopic clusters of Purkinje cells (enclosed by lines). Below and between these clusters of labeled Purkinje cells are the unstained cerebellar nuclear neurons. The thick vertical dash marks the midline. $C, D$, Comparison of Purkinje cell placement in the flocculus of scrambler $(C)$ and reeler $(D)$ cerebellum. Normally positioned Purkinje cells (arrows) are more numerous in this region of the reeler cerebellum. $E$, $F$, The disposition of Purkinje cells is shown in the wild-type cerebellum at low $(E)$ and higher $(F)$ powers of magnification. Scale bar: $A, 200 \mu \mathrm{m} ; B, E, 400 \mu \mathrm{m} ; C, D, F, 100$.

parasagittal zebrin-positive bands of Purkinje cells between the scrambler and reeler mutant cerebella are apparent (Fig. $3 C$ ).

In postnatal day 6 scrambler cerebellum, the ectopic masses of Purkinje cells are bordered by regions of intense tenascin and GFAP immunoreactivity (Fig. $4 A, B$ ). This same disposition of matrix and glial components is found in the reeler cerebellum (Fig. $4 C$ ). The normal cerebellum also displays GFAP and tenascin labeling, but these markers are most intense in the white matter and molecular layers, and they do not show an obvious relationship to Purkinje cells (data not shown). In coronal sec- 

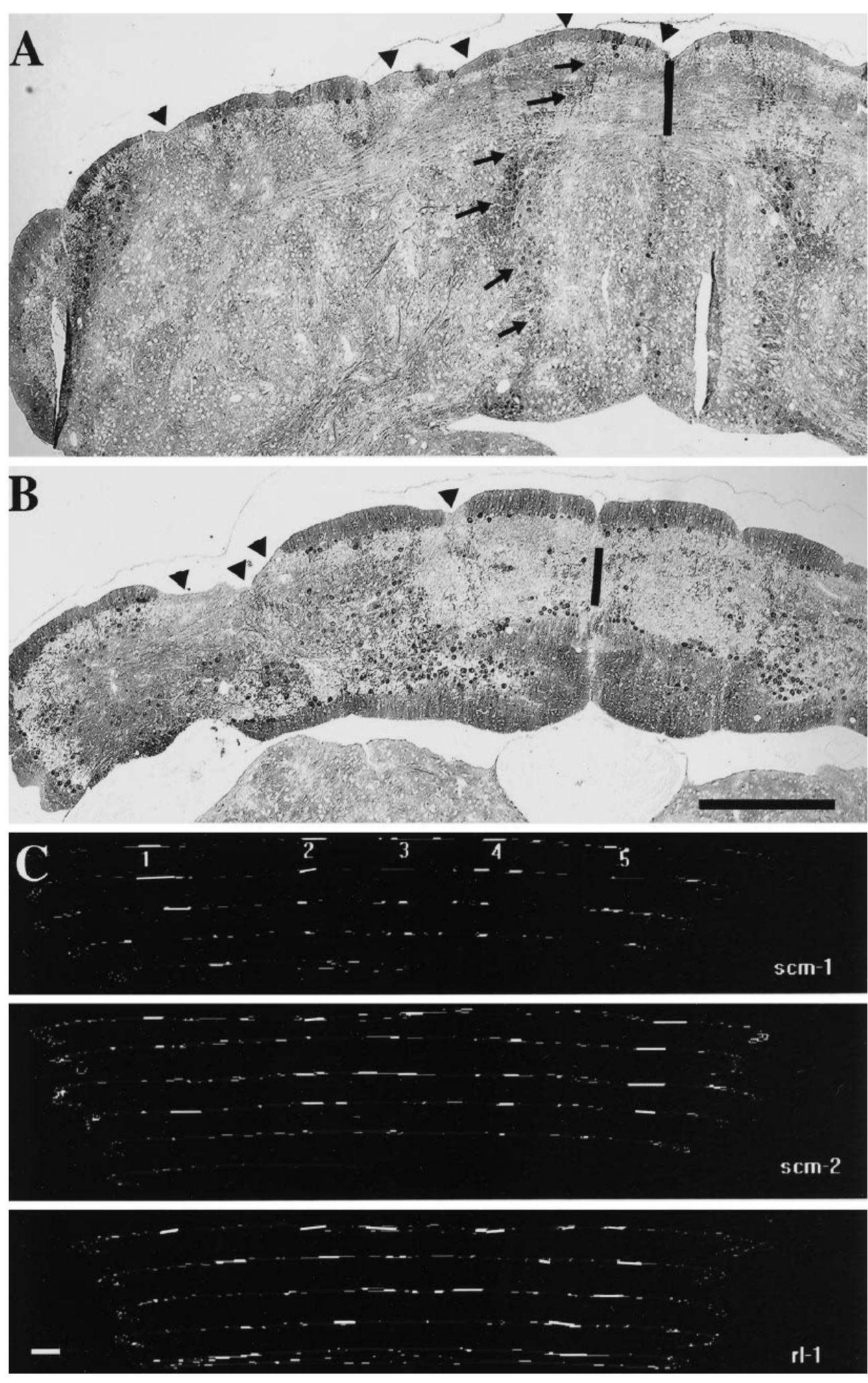

Figure 3. Parasagittal organization of Purkinje cells in the scrambler cerebellum. $A$, Anti-zebrin immunocytochemistry in the anterior part of the $\mathrm{scm} / \mathrm{scm}$ cerebellum is shown in this coronal section. Zebrin-positive Purkinje cells extend from the poorly populated Purkinje cell layer through to deeper populations of ectopic cells (arrows). Zebrin-negative zones are marked by arrowheads. B, Zebrin immunopositivity in the posterior scrambler cerebellum is depicted in this micrograph from the same brain illustrated in $A$. Note that most of the Purkinje cells are zebrin-positive, with only a few, small interspersed bands of zebrinnegative cells (arrowheads). C, Reconstruction of zebrin-positive (gray) and zebrin-negative (white) parasagittal zones is shown in two scrambler (scm-1, scm-2) and one reeler $(r l-1)$ cerebellum. Five main zebrin-off zones (numbered from 1 to 5 , with zone 3 marking or straddling the midline) can be discerned in both scrambler and reeler cerebella. The tracings are from coronal sections arranged from anterior (top) to posterior (bottom) and are scaled to intersampling intervals of $\sim 240 \mu \mathrm{m}$. In both scrambler cases the last section that was sampled was of a half cerebellum. Scale bar: $A, B, 500 \mu \mathrm{m} ; C$, $240 \mu \mathrm{m}$. tions midway through the scrambler cerebellum, the bilateral paired masses of Purkinje cells are separated by a striking GFAP and tenascin immunoreactive midline raphe (Fig. 4B). This immunopositive raphe is also present in reeler mutant cerebella (Fig. $4 C$ ), but we have not observed such a midline structure in the normal cerebellum.

\section{Quantitative features of the scrambler cerebellum}

Although the medial to lateral extent of the $\mathrm{scm} / \mathrm{scm}$ cerebellum is near normal, the total volume is reduced by $>50 \%$ compared with $+/ \mathrm{scm}$ mice $\left(4.4 \times 10^{9} \mu^{3}\right.$ for the $\mathrm{scm} / \mathrm{scm}$ half cerebellum compared with $9.6 \times 10^{9} \mu \mathrm{m}^{3}$ for the $+/ \mathrm{scm}$ half cerebellum). This difference reflects a squat, unfoliated cerebellar cortex in the 

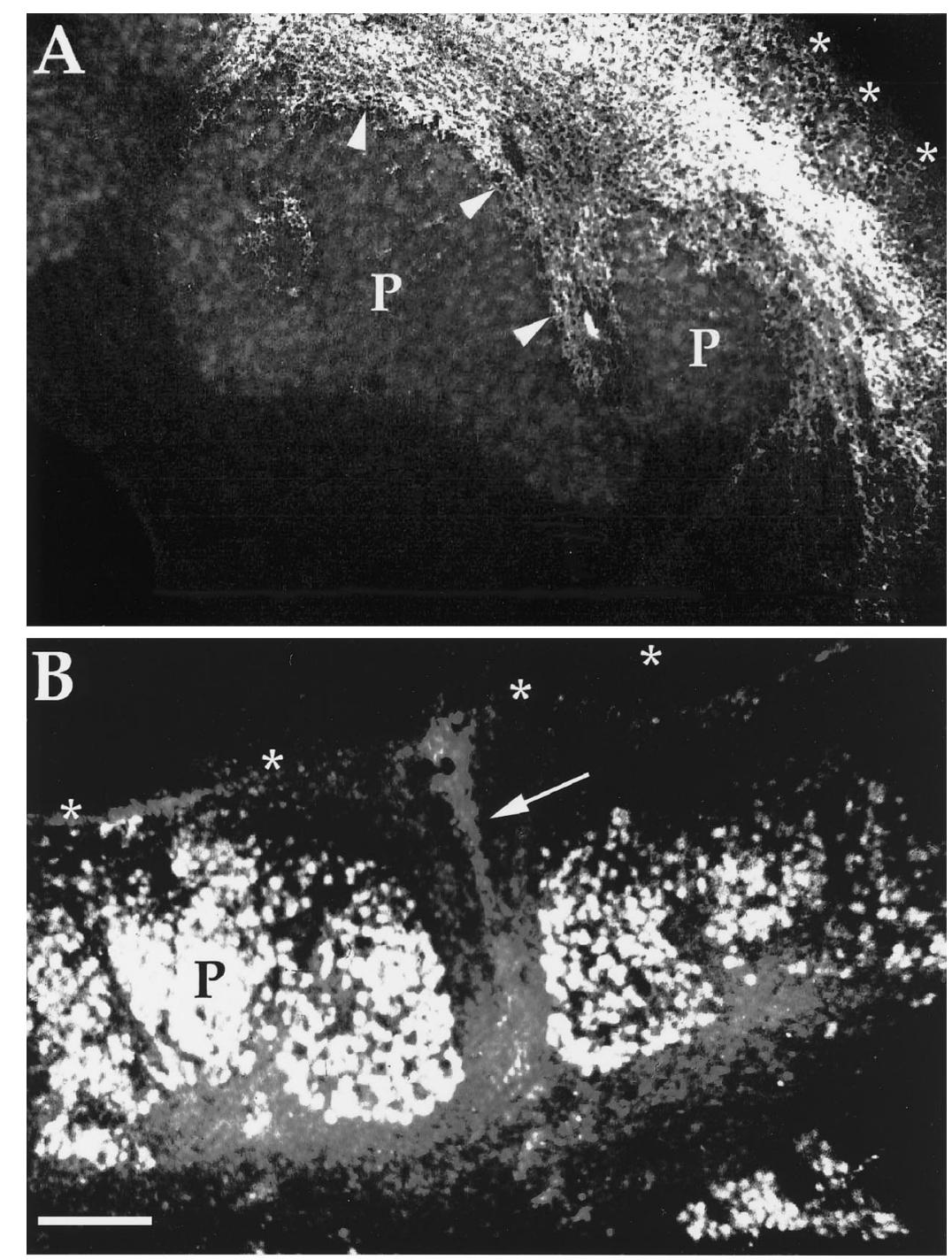

Figure 4. Glial and ECM boundaries between clusters of ectopic Purkinje cell masses in early postnatal $\mathrm{scm} / \mathrm{scm}$ and $\mathrm{rl} / \mathrm{rl}$ cerebella. $A$, Double immunofluorescence of flattened tangential sections reveals islands of rhodamine-labeled, calbindinpositive Purkinje cells $(P$, rather dim in this black and white image) separated by areas of intense fluorescein tenascin labeling (arrowheads delineate border between Purkinje cells and tenascin boundary). $B$, Double immunofluorescence of a coronal section reveals a midline GFAP-positive glial raphe (rhodamine label with dimmer appearance, arrow) between two calbindin-positive Purkinje cell masses $(P$, brightappearing fluorescein label). $C$, GFAP-positive immunofluorescence at the midline in the reeler cerebellum (arrow). Asterisks mark the pial surface. Scale bar, $100 \mu \mathrm{m}$.

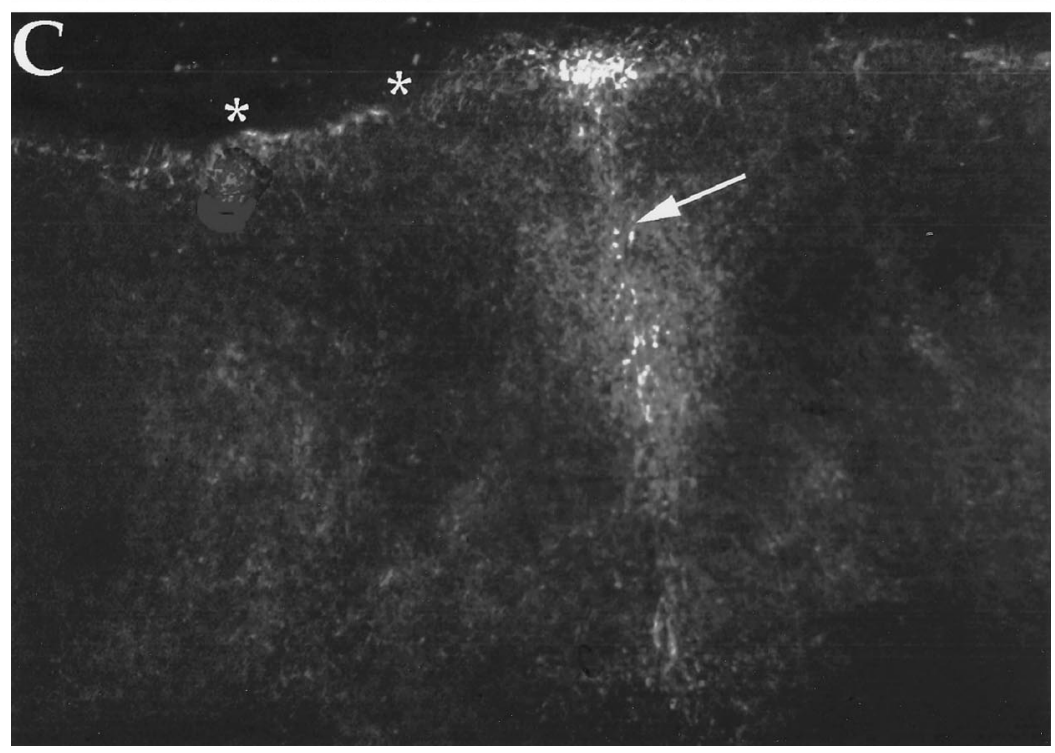

scrambler mutant mouse. The decreased volume of the scrambler half cerebellum is similar to the decreased volume of the reeler half cerebellum $\left(4.5 \times 10^{9} \mu^{3}\right)$. Estimates from single sections through scrambler, reeler, and heterozygous normal littermate cerebella suggest that there is a fivefold reduction in the number of scrambler and reeler granule cells (9000 cells in a midline sagittal section of a mutant cerebellum compared with 45,000 in a wild-type cerebellum). 


\begin{tabular}{|c|c|c|c|c|}
\hline \multirow{2}{*}{$\begin{array}{l}+/ \mathrm{scm} \text { Purkinje } \\
\text { cells }\end{array}$} & \multicolumn{2}{|c|}{$\mathrm{scm} / \mathrm{scm}$ Purkinje cells } & \multicolumn{2}{|c|}{$r l / r l$ Purkinje cells } \\
\hline & Total & Normally placed ${ }^{a}$ & Total & Normally placed ${ }^{a}$ \\
\hline \multirow[t]{5}{*}{92,192} & 84,021 & $4520(5.4)$ & 70,567 & $4397(6.2)$ \\
\hline & 87,380 & $4932(5.6)$ & 72,989 & $6113(8.4)$ \\
\hline & 77,413 & $3324(4.3)$ & & \\
\hline & 75,833 & $4107(5.4)$ & & \\
\hline & $81,161 \pm 2727$ & $4,220 \pm 343(5 \pm 0.3)$ & $71,778 \pm 1211$ & $5,255 \pm 858(7.3 \pm 1.1)$ \\
\hline
\end{tabular}

\footnotetext{
${ }^{a}$ Number of Purkinje cells present in a Purkinje cell layer. In parentheses is the percentage of total Purkinje that are normally placed.
}

The Purkinje cell population was determined for the scrambler cerebellum in a manner similar to that previously used for reeler (Heckroth et al., 1989). Estimates of Purkinje cell number were made for half cerebella from four $\mathrm{scm} / \mathrm{scm}$ mice (two sectioned in the sagittal plane and two sectioned in the coronal plane). An estimate of the total number of control Purkinje cells is about 92,000 as determined from a single $+/ \mathrm{scm}$ half cerebellum. Similar numbers of Purkinje cells have been reported in several inbred strains of mouse (84,000-94,000; Wetts and Herrup, 1983). The total number of Purkinje cells in scrambler was estimated to be $81,200 \pm 2700$. The population of normally placed Purkinje cells averaged $4200 \pm 300$, or $\sim 5 \%$ of the total population. This percentage of normally positioned Purkinje cells is similar to that previously determined for reeler, although the total number of Purkinje cells in scrambler was higher than that reported in the reeler cerebellum (Heckroth et al., 1989). To determine whether technical differences, such as the use of different antibodies [calbindin in this study versus cGMP-dependent protein kinase in a study by Heckroth et al. (1989)], could account for our estimates in scrambler compared with the reported counts in reeler, two of the above scrambler brains were prepared in parallel with two reeler brains and stained with the anti-calbindin antibody. Our estimate of reeler Purkinje cell number was 71,800 $\pm 1200(n=$ 2) (Table 1), not as different from scrambler as suggested by the quantitative studies of Heckroth et al. (1989; 41,000 per half cerebellum) but still less than the number of scrambler Purkinje cells. It is possible that the differences observed in our analysis between scrambler and reeler Purkinje cell numbers are attributable to documented differences in total number of Purkinje cells between inbred strains of mice (Wetts and Herrup, 1983).

\section{Birth dating Purkinje and granule cells in the scrambler cerebellum}

To compare the birth date and final address of Purkinje and granule cells in adult scrambler and control mice, we injected the DNA analog BrdU at embryonic ages 10.5-16.5 and postnatal ages $0-21 \mathrm{~d}$. In the cerebral cortex there are well defined abnormalities in the placement of neurons based on their birth date in both reeler and scrambler mice (Caviness and Sidman, 1973; Caviness, 1982; González et al., 1997). This issue is more ambiguous in the cerebellum, because the granule cells show normal migratory paths, and only Purkinje cells display aberrations in migration.

Our analysis indicates that both Purkinje and granule cells are born during the normal period of neurogenesis in the scrambler cerebellum. Purkinje cells are labeled during E11-E13 but not at E10.5 or E16.5. Normally positioned Purkinje cells in the scrambler cerebellum are also born during this period (Fig. $5 A$ ). Many strongly BrdU-positive granule cells are found after BrdU injec- tions at P5-P15, but very few are identified at P0 or P21 (Fig. 5B). Finally, birth-dated cohorts of mutant Purkinje and granule cells have a general spatial distribution similar to those of neurons born at the same time in the wild-type cerebellum (Fig. 5).

\section{Expression of reelin in the scrambler cerebellum}

To investigate whether scrambler mice express Reln mRNA, we examined total brain RNA from postnatal day 12-14 normal and homozygous mutant scrambler and reeler pups by Northern hybridization analysis. Hybridization with a Reln cDNA probe reveals a single transcript of $\sim 12 \mathrm{~kb}$ that is present in equal quantities in normal and scrambler mice but that is absent in reeler mice (Fig. 6A). These results are consistent with the previous report that reelin expression is abolished in reeler mice of the Edinburgh strain (D'Arcangelo et al., 1995). Furthermore, the results demonstrate that reelin mRNA expression in the brain of homozygous scrambler mice is not affected by this mutation.

To determine whether reelin protein is produced by homozygous scrambler cells, we prepared cerebellar primary cultures from postnatal day 6 normal and homozygous scrambler pups. The cultures were labeled overnight with a mixture of $\left[{ }^{35} \mathrm{~S}\right] \mathrm{me}$ thionine and $\left[{ }^{35} \mathrm{~S}\right]$ cysteine as described in Materials and Methods. When the culture medium is subjected to immunoprecipitation with the anti-reelin monoclonal antibody CR-50 (Ogawa et al., 1995; D'Arcangelo et al., 1997), a major protein of $\sim 400 \mathrm{kDa}$ is present in samples from normal cerebellum (Fig. 6B). This protein corresponds to a secreted, glycosylated form of full-length reelin (D'Arcangelo et al., 1997). In addition, we find that a similar reelin band is observed in the sample obtained from scrambler mice (Fig. 6B). These data indicate that scrambler cerebellar cells synthesize and secrete full-length reelin, which is indistinguishable from the protein produced by normal mice.

\section{DISCUSSION}

\section{Mutant phenotypes in scrambler and reeler}

Here we demonstrate that the anatomical structure of the cerebellum in the scrambler mutant mouse is essentially identical to that of reeler. Similarly, the aberrant lamination and perturbed inside-out development of the scrambler cortex are identical to those in reeler (González et al., 1997). The hippocampal formation is also strikingly similar, including a multilayering of pyramidal cells in the hippocampus and unorganized granule cells in the dentate gyrus (Sweet et al., 1996) (D. Goldowitz, unpublished observations). However, in view of the fact that we find normal levels of reelin mRNA and protein in scrambler, these data imply that $\mathrm{scm}$ codes for a distinct gene that is critically involved in neuronal migration in a manner similar to Reln.

The most remarkable alteration in the scrambler mutant brain 


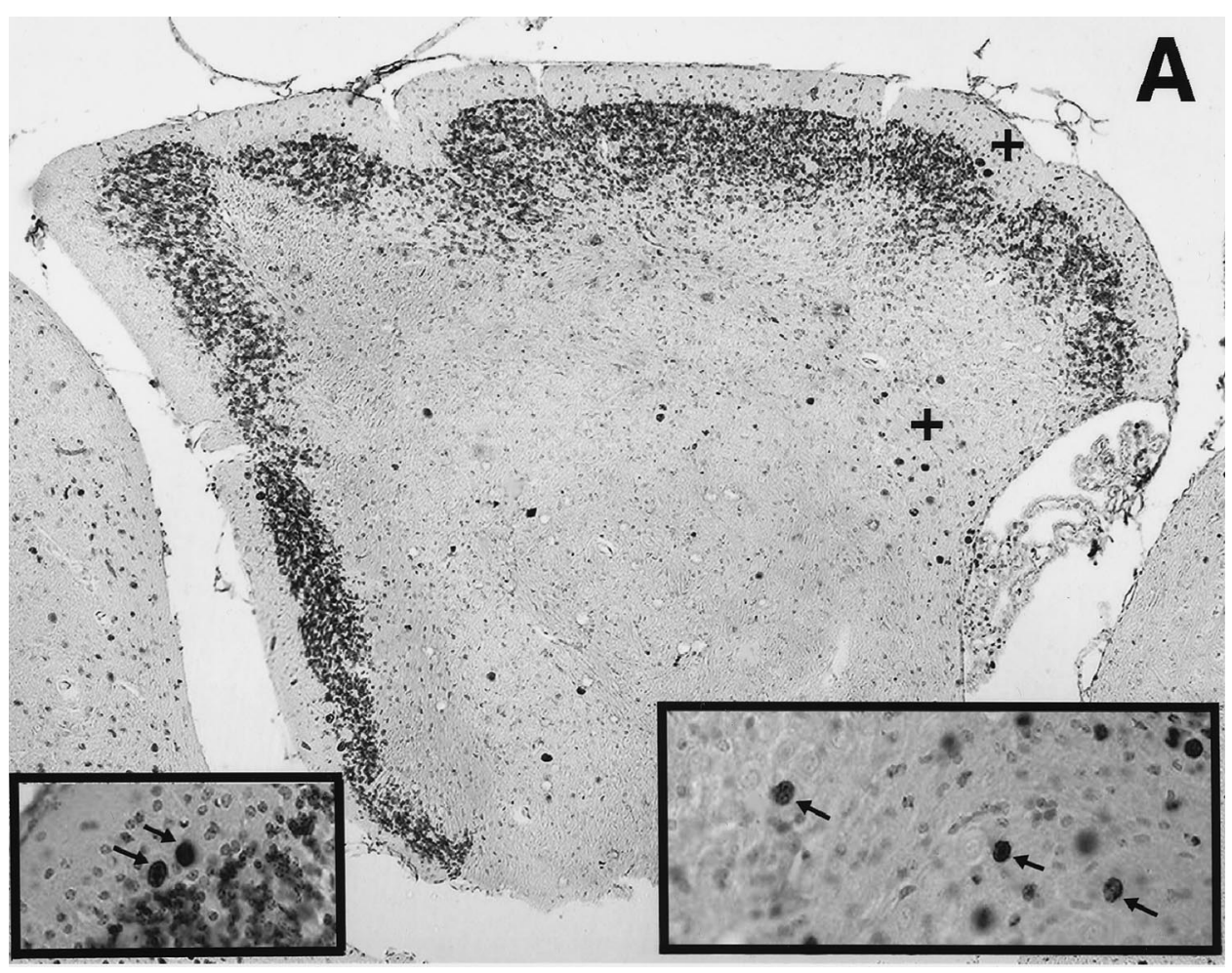

Figure 5. Birth date analysis of scrambler Purkinje and granule cells. $A$, Sagittal section of a mature cerebellum processed for $\mathrm{BrdU}$ immunohistochemistry and cresyl violet after an injection of BrdU at E12.5. Labeled Purkinje cells are found throughout the deep clusters but are more concentrated in the posterior portion of the cerebellum $(+$ marks this region, and the right inset shows some of the labeled cells at higher magnification, $a r$ rows). Two normally positioned Purkinje cells are clearly evident in the posterior cerebellum ( + in molecular layer and left inset shows the labeled cells at higher magnification, arrows). In other sections, labeled Purkinje cells were found clustered in the anterior cerebellum. This preferential placement of Purkinje cells labeled at E12.5 in scrambler is similar to that seen in the wild-type cerebellum after tritiated thymidine injections at E12-E13 (Inouye and Murakami, 1980). B, Adult scrambler cerebellum processed for BrdU immunostaining after a postnatal day 11.5 injection of BrdU. Labeled granule cells are present throughout the internal granule cell layer. Right inset, Underlined region at higher magnification. Arrows point to some of the many labeled granule cells. Left inset, BrdU-processed and cresyl violet-counterstained cerebellum of a $+/ \mathrm{scm}$ littermate with labeled granule cells similarly dispersed throughout the granule cell layer (arrows). Magnification: $A, B, 60 \times$; insets, $180 \times$.

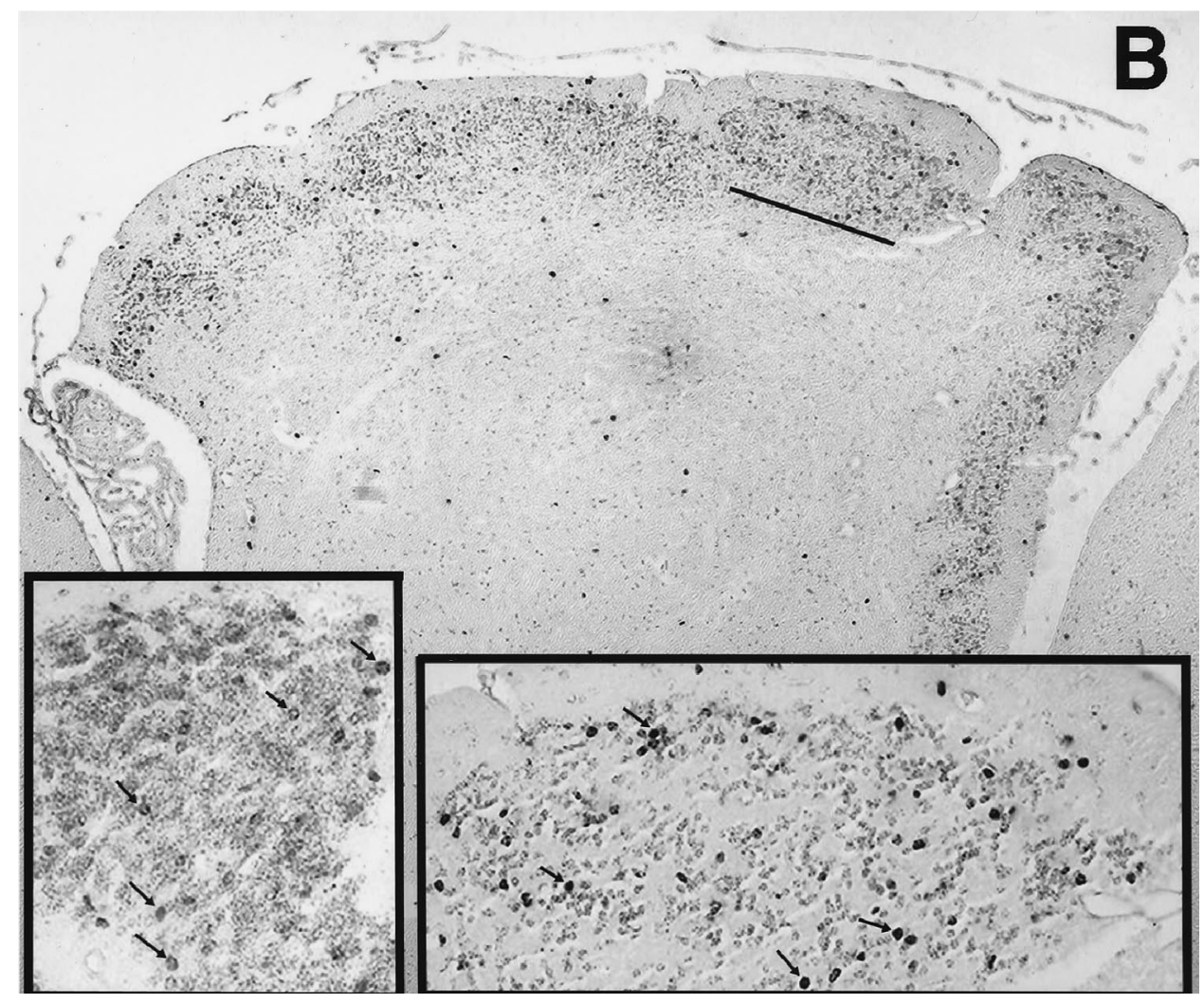

is the diminutive and unfoliated cerebellum that is a consequence of a large decrease in the granule cell population and a failure of the majority of Purkinje cells to complete migration. This cerebellar phenotype is a very close approximation of the situation in the reeler mouse. The similarities between scrambler and reeler cerebella include qualitative features, such as the lack of foliation, the cell-free notch at the presumed site of the primary fissure, the normally placed but greatly reduced number of granule cells, the disposition of cerebellar nuclear neruons, the ectopic location of Purkinje cells and their parasagittal parceling by zebrin II immunohistochemistry, and quantitative features, such as the reduction in Purkinje cell number and the relatively constant percentage of normally placed Purkinje cells. Included in this list of similarities is the identification of a novel anatomic structure in both reeler 
A

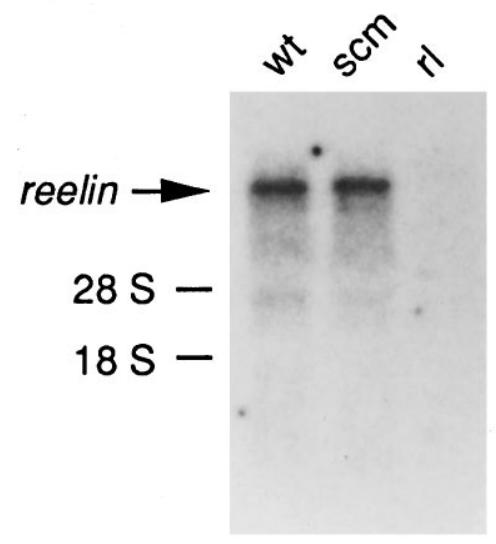

B

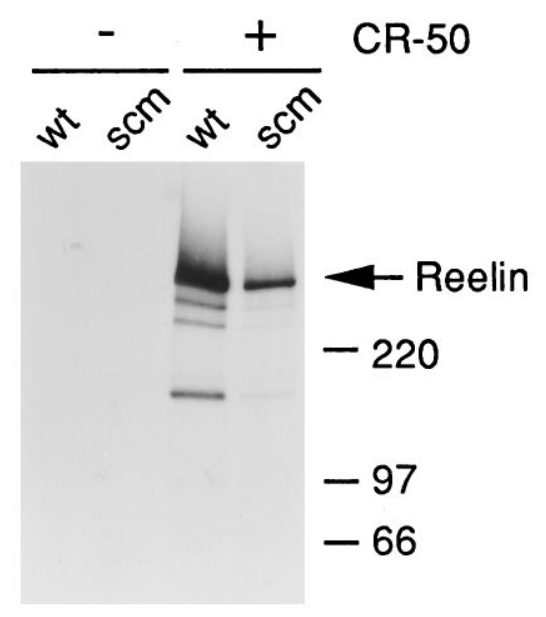

Figure 6. Reelin is expressed normally in the scrambler brain. A, Northern blot analysis of Reelin mRNA. Total RNA (10 $\mu \mathrm{g} /$ lane) was isolated from wild-type $(w t), s c m$, or Reln brain at postnatal day 14 and electrophoresed through a $1 \%$ formaldehyde-agarose gel. The RNA was transferred to a nylon membrane, and the blot was hybridized with a ${ }^{32} \mathrm{P}$-labeled Reln antisense riboprobe. Reelin mRNA $(\sim 12 \mathrm{~kb})$ is not expressed in reeler mice, but it is expressed in scrambler as well as normal mice. The migration of the 28 and $18 \mathrm{~S}$ ribosomal bands is indicated. $B$, Immunoprecipitation of reelin from the medium of cerebellar cultures. Cerebellar cultures were established from postnatal day 7 wild-type $(w t)$ or $\mathrm{scm} / \mathrm{scm}$ mice. The cultures were metabolically labeled with $\left[{ }^{35}\right.$ S $]$ methionine and $\left[{ }^{35}\right.$ S $]$ cysteine. Proteins in the medium were subjected to immunoprecipitation in the presence $(+)$ or absence $(-)$ of the anti-reelin monoclonal antibody CR-50 and analyzed by SDS-PAGE on a $4-12 \%$ gel. Reelin $(\sim 400 \mathrm{kDa})$ was detected in the medium of both normal and $\mathrm{scm}$ cultures. Molecular weight markers are indicated in kilodaltons.

and scrambler that is missing in normal brain: a midline glial raphe positioned between the left and right halves of the cerebellum. The only variations found between scrambler and reeler cerebella are differences in Purkinje cell number and alterations in Purkinje cell placement in the floccular lobe. These discrepancies are rather minor, and they could well be attributable to strain background effects as opposed to more direct effects of the scm and/or Reln genes. In either case, the scrambler cerebellum is a high-fidelity copy of the reeler cerebellum.

\section{Scrambler cerebellum and neurodevelopment}

Our phenotypic analysis of the scrambler cerebellum raises interesting issues concerning mechanisms of cerebellar development. Previous studies of glia and extracellular matrix (ECM) molecules during development have shown that these elements are highly concentrated in boundaries around different functional units (including whisker barrels, striosomes, subcortical nuclei; for review, see Steindler et al., 1989). These developmental boundaries also have been described around the Purkinje cell central cerebellar mass of the developing reeler mouse cerebellum, best seen using immunocytochemistry for tenascin (Steindler et al., 1990). In the present study, immunocytochemistry for tenascin reveals identical patterns of tenascin-rich boundaries around clusters of Purkinje cells in scrambler. These astroglial, tenascin-rich areas are interpreted to be structures rich in boundary molecules that may be involved in morphogenetic functions distinct from those occurring in ECM-poor areas (e.g., the Purkinje cell clusters). This unusual placement of ECM may be a consequence of abnormal development in reeler and scrambler or part of the causal set of circumstances that underlie the neuronal ectopia seen in the mutant cerebellum. It is possible that the absence of functional reelin, or its downstream partners, leads to defective signaling attributable to inappropriate matrix-neuronal-glial interactions and ectopia of Purkinje cells.

We also see another distinct pattern of boundary labeling in the developing scrambler and reeler cerebellum that arises in the midline, as revealed with immunocytochemistry for the astrocyte intermediate filament protein GFAP. A GFAP-positive, glial midline septum has been described in the developing and adult caudal brain stem (Van Hartesveldt et al., 1986; Mori et al., 1990) and along midline boundaries in the developing roof plate of the spinal cord and optic tectum (Snow et al., 1990). The alar plates of the embryonic metencepthalon start to fuse at the midline early in cerebellar morphogenesis, and the glial septum observed in the scrambler and reeler cerebellum appears to be a permanent vestige of normal cerebellar midline development. This suggests that development may be arrested in reeler and scrambler mice. The midline glial raphe may be a dorsal continuance of the aforementioned brainstem glial raphe structures, because there are reports of persistent GFAP-positive "strong midline raphe" in the cerebellum of the turtle (Kalman et al., 1994). Thus, in addition to a midline glial raphe distinguishing the cerebellum of both scrambler and reeler, it may also be a key element in cerebellar development and function in a variety of species.

Although granule cell migration is normal in scrambler and reeler mice, the end result is a greatly diminished population of cells in the internal granule layer. This implies that the circumferential and radial migration of granule cells does not require reelin or the scm gene product. However, the mutations clearly result in a large depletion of granule cells. Mallet et al. (1976) suggested that Purkinje cells provide a trophic influence that supports granule neuroblast proliferation. This can also be inferred from studies in which there is an upregulated production of granule cells in response to granule cell loss in the proliferative zone of the external granule layer (Altman et al., 1969; Hamre and Goldowitz, 1997). Furthermore, the absence of Purkinje cells results in greatly diminished numbers of granule cells in the lurcher and staggerer mutants (Caddy and Biscoe, 1979; Wetts and Herrup, 1982; Herrup, 1983) and in mice in which Purkinje 
cells are ablated experimentally (Smeyne et al., 1995). Thus, it is possible that the scm and Reln genes either stimulate trophic factor release directly from Purkinje cells or that the ectopic position of these cells renders the signal inaccessible to granule cell neuroblasts. An alternative explanation is that Reln and scm themselves directly affect the proliferation and survival of granule cell neuroblasts.

\section{Clues to the molecular identity of scrambler}

Recently, two artificial mutations in the mouse that affect neuronal migration have been reported. Disruption of the neural specific gene $C d k 5$ and its partner $P 35$ produce perturbations of neocortical architecture similar to those of reeler and scrambler (Ohshima et al., 1996; Chae et al., 1997). However, neither of these mutants resemble reeler to the degree seen with scrambler. In the $C d k 5$ knock-out, the details of CNS abnormalities have not been well described, and the perinatal mortality associated with the defective gene hinders close comparisons. However, at birth, $C d k 5$ null mice exhibit abnormalities in neocortex, hippocampus, and cerebellum that resemble those of reeler and scrambler (Ohshima et al., 1996). In the case of $P 35$, gene disruption results in viable mice that have relatively normal hippocampal and cerebellar cytoarchitectonics but a cerebral cortex with migration abnormalities similar to that seen in reeler and scrambler (Chae et al., 1997). The lack of obvious phenotypes in the cerebellar and hippocampal cortices of $P 35$ null mice may be because other $C d k 5$ partners, such as $P 39$, are expressed in these tissues and may substitute for its function (Chae et al., 1997). It is possible that these genes also represent components of a molecular cascade that involves Reln and $\mathrm{scm}$.

Previous studies of mouse mutations that exhibit similar phenotypes have identified genes that function as components of a common signal transduction pathway. For example, the murine mutants dominant spotting and steel, which have very similar defects in hematopoeisis, gametogenesis, and melanogenesis, were found to represent lesions in the $c-k i t$ tyrosine kinase receptor and its ligand, mast cell growth factor (for review, see Fleischman, 1993). Similarly, artificial mutations, created by gene disruption, in receptor-ligand pairs can result in similar phenotypes when there is a singular relationship between receptor and ligand, as with the trk family of tyrosine protein kinase receptor and neurotrophin genes (Crowley et al., 1994; Ernfors et al., 1994; Klein et al., 1994; Smeyne et al., 1994). Thus, it is tempting to speculate that there is a close biochemical relationship between the protein products of the Reln and $s \mathrm{~cm}$ genes. The fact that we find normal processing and secretion of reelin and normal levels of Reln mRNA in scrambler brain indicates that the scrambler gene acts downstream of reelin in a common signaling pathway that controls cell migration during neural development.

Reelin is secreted by the early born neurons in brain, such as the Cajal-Retzius cells of the neocortex (D'Arcangelo et al., 1995; Hirotsune et al., 1995, Ogawa et al., 1995). In the embryonic cerebellum, granule cell precursors and a population of nuclear neurons express reelin (D'Arcangelo et al., 1995; Miyata et al., 1996). Because reelin is secreted into the extracellular matrix, it is thought to interact with a target that is either present in the matrix or associated with the cell surface. In the cerebellar cortex, the target cells of reelin are likely to be the Purkinje cells, because extracellular reelin is found to accumulate on Purkinje cell processes (Miyata et al., 1996). Furthermore, the alignment of wildtype Purkinje cells in embryonic explant cultures can be disrupted by treatment with anti-reelin CR-50 antibody (Miyata et al., 1997). Thus, it is possible that Purkinje cells remain clustered in the deep cerebellar cortex because they fail to receive a reelin signal that promotes dispersion and migration to the Purkinje cell plate. The neuroanatomic and experimental data suggest that reelin may directly activate signaling pathways present in Purkinje cells. The effects of reelin on Purkinje neurons could also be mediated indirectly by radial glia of the cerebellum (the so-called Bergmann glia or Golgi epithelial cells), because these cells are believed to be critical for neuronal migration. Recently, we identified the gene mutated in scrambler as $m D a b 1$, which is related to the Drosophila disabled (Dab) gene (Sheldon et al., 1997). The protein product of $m D a b 1$ appears to function as an intracellular component of a tyrosine kinase cascade. $m D a b 1$ is expressed in the developing brain (Howell et al., 1997), and targeted disruption of $m D a b 1$ leads to a reeler/scrambler phenotype (Howell et al., 1997). mDab1 is expressed in Purkinje cells and in migrating neurons in the cortical plate (Sheldon et al., 1997). The findings suggest that $m D A b 1$ functions in the target cells of Reelin, and that it acts as a component of a signaling pathway stimulated by reelin.

\section{REFERENCES}

Abercrombie M (1946) Estimation of nuclear population from microtome sections. Anat Rec 94:239-247.

Altman J, Anderson WJ, Wright KA (1969) Reconstitution of the external granular layer of the cerebellar cortex in infant rats after low-level x-irradiation. Anat Rec 163:453-472.

Caddy K, Biscoe T (1979) Structural and quantitative studies on the normal $\mathrm{C} 3 \mathrm{H}$ and Lurcher mutant mouse. Philos Trans R Soc Lond [Biol] 287:167-201.

Caviness VS (1977) The reeler mutant mouse: a genetic experiment in developing mammalian cortex. In: Society for Neuroscience symposium, Vol 2 (Cowan WM, Ferrendelli JA, eds), pp 27-46. Bethesda, MD: Society for Neuroscience.

Caviness VS (1982) Neocortical histogeneisis in normal and reeler mice: a developmental study based upon $\left({ }^{3} \mathrm{H}\right)$ thymidine autoradiography. Dev Brain Res 4:293-302.

Caviness VS, Sidman RL (1973) Retrohippocampal, hippocampal and related structures of the forebrain in the reeler mutant mouse. J Comp Neurol 147:235-254.

Caviness VS, Pinto-Lord MC, Evrard P (1981) The development of laminated pattern in the mammalian neocortex. In: Morphogenesis and pattern formation (Connelly TG, Brinkley LL, Carlson BM, eds), pp 103-126. New York: Raven.

Chae T, Kwon YT, Bronson R, Dikkes P, Li E, Tsai LH (1997) Mice lacking p35, a neuronal activator of C dk5, display cortical lamination defects, seizures, and adult lethality. Neuron 18:29-42.

Crowley C, Spencer SD, Nishimura MC, Chen KS, Pitts-Meek S, Armanini MP, Ling LH, MacMahon SB, Shelton DL, Levinson AD, Phillips H (1994) Mice lacking nerve growth factor display perinatal loss of sensory and sympathetic neurons yet develop basal forebrain cholinergic neurons. Cell 76:1001-1011.

D'Arcangelo G, Miao GG, Chen SC, Soares HD, Morgan JI, Curran T (1995) A protein related to extracellular matrix proteins deleted in the mouse mutant reeler. Nature 374:719-723.

D'Arcangelo G, Nakajima K, Miyata T, Ogawa M, Mikoshiba K, Curran T (1997) Reelin is a secreted glycoprotein recognized by the CR-50 monoclonal antibody. J Neurosci 17:23-31.

Edwards MA, Leclerc N, Crandall JE, Yamamoto M (1994) Purkinje cell compartments in the reeler mutant mouse as revealed by Zebrin II and 90 -acetylated glycolipid antigen expression. Anat Embryol (Berl) 190:417-428.

Ernfors P, Lee KF, Kucra J, Jaenisch R (1994) Lack of neurotrophin-3 leads to deficiencies in the peripheral nervous system and loss of limb proprioceptive afferents. Cell 77:503-512.

Fischer G (1982) Cultivation of mouse cerebellar cells in serum free, hormonally defined media: survival of neurons. Neurosci Lett 28:325-329.

Fleischman RA (1993) From white spots to stem cells: the role of the Kit receptor in mammalian development. Trends Genet 9:285-290.

Franco B, Guioli S, Pragliola A, Incerti B, Bardoni B, Tonlorenzi R, 
Carrozzo R, Maestrini E, Pieretti M, Taillon-Miller P, Brown CJ, Willard JF, Lawrence C, Persico MG, Camerino G, Ballabio A (1991) A gene deleted in Kallmann's syndrome shares homology with neural cell adhesion and axonal path-finding molecules. Nature 353:529-536.

Goffinet AM (1983) The embryonic development of the cerebellum in normal and reeler mutant mice. Anat Embryol 168:73-86.

Goffinet AM (1984) Events governing organizaion of postmigratory neurons: studies on brain development in normal and reeler mice. Brain Res Rev 7:261-296.

Goffinet AM, So K-F, Yamamoto M, Edwards M, Caviness VS (1984) Architectonic and hodolgical organization of the cerebellum in reeler mutant mice. Dev Brain Res 16:263-276.

González JL, Russo C, Sweet H, Davisson M, Goldowitz D, Walsh C (1996) Neocortical birthdating analysis on scrambler, a novel mouse mutant, reveals a reeler-like phenotype. Soc Neurosci Abstr 22:393.13.

González JL, Russo CJ, Goldowitz D, Sweet HO, Davisson MT, Walsh C (1997) Birthdate and cell marker analysis of scrambler: a novel mouse mutation affecting cortical development with a reeler-like phenotype. J Neurosci, in press.

Hamre KM, Goldowitz D (1996) Analysis of gene action in the meander tail mutant mouse: examination of cerebellar phenotype and mitotic activity of granule cell neuroblasts. J Comp Neurol 368:304-315.

Hamre KM, Goldowitz D (1997) meander tail acts intrinsic to granule cell precursors to disrupt cerebellar development: analysis of meander tail chimeric mice. Development, in press.

Hattori M, Adachi H, Tsujimoto M, Aral H, Inoue K (1994) MillerDieker lissencephaly gene encodes a subunit of brain platelet-activating factor. Nature 370:216-218.

Heckroth JA, Goldowitz D, Eisenman LM (1989) Purkinje cell reduction in the reeler mutant mouse: a quantitative immunohistochemical study. J Comp Neurol 279:546-555.

Herrup K (1983) Role of staggerer gene in determining cell number in cerebellar cortex. I. Granule cell death is an indirect consequence of staggerer gene action. Dev Brain Res 12:271-283.

Hirotsune S, Takahara T, Sasaki N, Hirose K, Yoshiki A, Ohashi T, Kusakabe M, Murakami Y, Muramatso M, Watanabe S, Nakai K, Katsuki M, Hayashizaki Y (1995) The reeler gene encodes a protein with an EGF-like motif expressed by pioneer neurons. Nat Genet 10:77-83.

Hoffarth RM, Johnston JG, Krushel LA, van der Kooy D (1995) The mouse mutation reeler causes increased adhesion within a subpopulation of early postmitotic cortical neurons. J Neurosci 15:4838-4850.

Howell BW, Gertler FB, Cooper JA (1997) Mouse disabled (mDab1): a Src binding protein implicated in neuronal development. EMBO J 16:121-132.

Howell BW, Hawkes R, Soriano P, Cooper JA (1997) Neuronal position in the developing brain is regulated by mouse disabled. Nature, in press.

Inouye M, Murakami U (1980) Temporal and spatial patterns of Purkinje cell formation in the mouse cerebellum. J Comp Neurol 194:499-503.

Kalman M, Kiss A, Majorossay K (1994) Distribution of glial fibrillary acidic protein-immunopositive structures in the brain of the red-eared turtle (Pseudemys scripta elegans). Anat Embryol 189:421-434.

Klein R, Silos-Santiago I, Smeyne RJ, Lira SA, Brambilla R, Bryant S, Zhang L, Snider WD, Barbacid M (1994) Disruption of the neurotrophin-3 receptor gene trkC eliminates 1a muscle afferents and results in abnormal movements. Nature 358:249-251.

Legouis R, Jardelin JP, Levilliers J, Claverie JM, Compain S, Wunderle V, Millasseau P, Le Paslier D, Cohen D, Caterina D (1991) The candidate gene for the $\mathrm{X}$-linked Kallmann syndrome encodes a protein related to adhesion molecules. Cell 67:423-435.

Mallet L, Huchet M, Pougeois R, Changeux JP (1976) Anatomical, physiological and biochemical studies on the cerebellum from mutant mice. III. Protein differences associated with the weaver, staggerer and nervous mutations. Brain Res 103:291-312.

Mariani J, Crepel F, Mikoshiba K, Changeux JP, Sotelo C (1977) Anatomical, physiological and biochemical stuides of the cerebellum from reeler mutant mouse. Philos Trans R Soc Lond [Biol] 281:1-28.

Miyata T, Nakajima K, Aruga J, Takahashi S, Ikenaka K, Mikoshiba K, Ogawa M (1996) Distribution of a reeler gene-related antigen in the developing cerebellum: an immunohisotchemical study with an allogeneic antibody CR-50 on normal and reeler mice. J Comp Neurol 372:215-228.

Miyata T, Nakajima K, Mikoshiba K, Ogawa M (1997) Regulation of Purkinje cell alignment by Reelin as revealed with CR-50 antibody. J Neurosci 17:3599-3609.

Mori K, Ikeda J, Hayaishi O (1990) Monoclonal antibody R2D5 reveals midsagittal radial glial system in postnatally developing and adult brainstem. Proc Natl Acad Sci USA 87:5489-5493.

Ogawa M, Miyata T, Nakajima K, Yagyu K, Seike M, Ikenaka K, Yamamoto H, Mikoshiba K (1995) The reeler gene-associated antigen on Cajal-Retzius neurons is a crucial molecule for laminar organization of cortical neurons. Neuron 14:899-912.

Ohshima T, Ward JM, Huh C-G, Longenecker G,veeranna, Pant HC, Brady RO, Martin LJ, Kulkarni AB (1996) Targeted disruption of the cyclin-dependent kinase 5 gene results in abnormal corticogenesis, neuronal pathology and perinatal death. Proc Natl Acad Sci USA 93:11173-11178.

Reiner O, Albrecht U, Gordon M, Chianese KA, Wong C, Gal-Gerber O, Sapir T, Siracusa LD, Buchberg AM, Caskey CT, Eichele G (1995) Lissencephaly gene (LIS1) expression in the CNS suggests a role in neuronal migration. J Neurosci 15:3730-3738.

Sheldon M, Rice DS, D'Arcangelo G, Yoneshima H, Nakajima K, Mikoshiba K, Howell B, Cooper JA, Goldowitz D, Curran T (1997) Scrambler and yotari disrupt the mouse disabled gene and produce a reeler-like phenotype in mice. Nature, in press.

Smeyne RJ, Klein R, Schnapp A, Long LK, Bryant S, Lewin A, Lira SA, Barbacid M (1994) Severe sensory and sympathetic neuropathies in mice carrying a disrupted Trk/NGF receptor gene. Nature 368:246-249.

Smeyne RJ, Che TG, Lewin A, Bian F, S-Crisman S, Kunsch C, Lira SA, Oberdick J (1995) Local control of granule cell generation by Purkinje cells. Mol Cell Neurosci 6:230-251.

Snow DM, Steindler DA, Silver J (1990) Molecular and cellular characterization of the glial roof plate of the spinal cord and optic tectum: a possible role for a proteoglycan in the development of an axon barrier. Dev Biol 138:359-376.

Steindler DA, Faissner A, Schachner M (1989) Brain "cordones": glial and adhesion molecule-transient boundaries define developing functional units. Comments Dev Neurobiol 1:29-60.

Steindler DA, O'Brien TF, Laywell E, Harrington K, Faissner A, Schachner M (1990) Boundaries during normal and abnormal brain development: in vivo and in vitro studies of glia and glycoconjugates. Exp Neurol 109:35-56.

Sweet HO, Bronson RT, Johnson KR, Davisson MT (1996) Scrambler, a new neurological mutation of the mouse with abnormalities of neuronal migration. Mamm Genome 7:798-802.

Van Hartesveldt C, Moore B, Hartman BK (1986) Transient midline raphe glial structure in the developing rat. J Comp Neurol 253:175-184.

Wetts R, Herrup K (1982) Interaction of granule, Purkinje and inferior olivary neurons in Lurcher chimeric mice. II. Granule cell death. Brain Res 250:358-362.

Wetts R, Herrup K (1983) Direct correlation between Purkinje and granule cell number in the cerebella of lurcher chimeras and wild type mice. Dev Brain Res 10:41-47. 